\title{
CHEMICAL INNOVATION IN PLANT NUTRITION IN A HISTORICAL CONTINUUM FROM ANCIENT GREECE AND ROME UNTIL MODERN TIMES
}

\author{
INNOWACJE CHEMICZNE W ODŻYWIANIU ROŚLIN \\ OD STAROŻYTNEJ GRECJI I RZYMU PO CZASY NAJNOWSZE
}

\begin{abstract}
This monograph aims to present how arduously views on plant nutrition shaped over centuries and how the foundation of environmental knowledge concerning these issues was created. This publication also presents current problems and trends in studies concerning plant nutrition, showing their new dimension. This new dimension is determined, on one hand, by the need to feed the world population increasing in geometric progression, and on the other hand by growing environmental problems connected with intensification of agricultural production.
\end{abstract}

Keywords: chemical innovations, plant nutrition

\section{Introduction}

Plant nutrition has been of great interest since time immemorial, at first among philosophers, and later among researchers. The history of environmental discoveries concerning the way plants feed is full of misconceptions and incorrect theories. Learning about the multi-generational effort to find an explanation for this process that is fundamental for agriculture shows us the tenacity and ingenuity of many outstanding personalities and scientists of that time. It also allows for general reflection which shows that present-day knowledge (which often seems obvious and simple) is the fruit of a great collective effort of science.

\section{Antiquity}

Already in ancient Greece people were interested in life processes of plants, the way they feed, and in the conditions that facilitate or inhibit their growth. In the Odyssey (8th century BC), Homer names manure as a material that improves plant growth. Next to

\footnotetext{
${ }^{1}$ Department of Agricultural and Environmental Chemistry, Hugo Kołłątaj University of Agriculture in Krakow, ul. A. Mickiewicza 21, 31-120 Kraków, Poland, phone +48 1266243 45, email: rrantonk@ cyf-kr.edu.pl

${ }^{2}$ Department of Soil Environment Sciences, Warsaw University of Life Sciences, ul. Nowoursynowska 159, 02-776 Warszawa, Poland, phone +48 22593 26 21, email: jan_labetowicz@sggw.pl

*Corresponding author: rrantonk@cyf-kr.edu.pl
} 
manure, also compost, straw, animal residues, river and pond silt, green manure, and sometimes even ash, bones, marl, lime and gypsum have been recommended to be used for soil fertilization [1, 2]. In the 5th century BC, Anaxagoras (500-428 BC) in his Peri physeon (Concerning Nature) as well as other philosophers believed that plants were 'soulful' organisms having the ability to react to environmental conditions, for example sadness or joy. Aristotle (384-322 BC) taught that plants take up food from soil through roots in a ready form, i.e. in the form of organic substances which can be found in a plant. $\mathrm{He}$ also assumed that plants have inner life which is manifested in the ability to think and in memory [3]. Theophrastus of Eresos (circa 370-287 BC), Aristotle's most brilliant student, thanks to in-depth studies on systematics, morphology, geography and physiology of plants, made an epochal contribution to biology and formulated the differences between the animal world and the plant world. He introduced classification of the plant world (maintained until the 16th century) into 4 groups, described approximately 500 plant species, showed the ways in which they reproduce and their use in different fields of life, characterized plant excitability, and established that vegetative structures include the root, stem, and leaves [4]. According to Columella, Marcus Porcius Cato (234-149 BC) was the first to become interested in agriculture in Rome. In Cato's lifetime there was only one treatise on agriculture; it was written in Latin and entitled De agri cultura (On Agriculture). This treatise forms a series of instructions and recommendations leading to a smart farm management system to achieve better commercial efficiency. In the De agri cultura treatise, Cato gives advice on sowing, soil fertilization, grapevine and olive cultivation. The main motto of this work focuses on obtaining maximum profit from land cultivation with low expenditure. His work also includes, among other things, cooking recipes, medical and religious rules, advice on the supply and sale. Greek texts and Theophrastus' botanical works which can be found in the treatise De agri cultura had contributed to creating that work [5]. In ancient Rome, the army included about 500,000 soldiers at the end of the Republic (the end of the 1st century BC), and nearly 750,000 soldiers in the later period of the Roman Empire (5th century AD), and it required large supplies of food. In that period, approximately 7,500 kilograms of cereals a day was required for an average army, and one soldier consumed 1/3 ton of wheat a year. Other sources claim that soldiers in Brittany consumed 33.5 tons of wheat a day. The above-mentioned data indicates that food production, including cereals, covered large acreages and had to be assisted through fertilization with organic materials named by Homer, such as animal droppings, river sediments, silt from ponds, and mineral materials, which includes ashes from forest burning, bones, marl, lime, gypsum. Due to expansionist wars and a large demand for food for the army, the Romans invested in land cultivation. This is when 'specialization' in agriculture began, leading primarily to large-scale cultivation of grapevine, olives, or cereals [5].

\section{Middle Ages}

The fall of Rome after the barbarian invasion caused the fall of the entire Greek-Latin civilization. Achievements of that period had fallen into oblivion, but also the ancient world's knowledge was adopted by the Arabs and rediscovered in the Renaissance and at Europe's encounter with the Eastern culture. This led to translation of many works of ancient philosophers, which was not without importance for views regarding environmental sciences in Europe of that time [6]. In the late 11th and early 12th centuries cathedral 
schools spread throughout Western Europe, which meant moving the center of intellectual life from monasteries to cities. Cathedral schools were in turn replaced by universities established in major European cities. Contrary to church schools, access to education was open at universities, the curriculum was expanded to include secular fields, including environmental sciences. The oldest universities in Western Europe include Bologna, Paris, Oxford, Cambridge, Padova, Toulouse, Rome, Orleans, Florence, Pisa, Coimbra, and in Easter Europe - in Prague and Kraków. In the 16th century, the University of Bologna introduced environmental sciences, expanding laboratories and institutes. The paradigm of medieval science was based on using the knowledge of ancient philosophers and authors. In a sense, present-day science originated from analyses of that time. At that time it was the doctors, philosophers, botanists and clergymen who described the nature and dealt with plant nutrition. They went out in the field and studied plants in their natural habitat; they observed what was growing and where [7]. Many discoveries of that period were associated mainly with chemistry and botany, not with physiology and plant nutrition. In the Middle Ages, attention was drawn to the relationship between plant yield, growth and development on different soils. According to Fink [8], the yield from $1 \mathrm{~kg}$ of sowing material (grains) provided, on average soils, 3-4 kg of cereal grain between the 12th and 15th century, whereas currently it is approximately $50-60 \mathrm{~kg}$. Knowledge about plant nutrition was very scarce in that period, and agriculture led a predatory economy, because not much importance was attached to plant fertilization or to the return of nutrients taken away from soil with the yield.

\section{Early modern period, 16th-19th century}

At the turn of the 16th and 17th centuries, science of plant nutrition started to develop, from the philosophy of nature to experimental sciences that were based on chemical bases. Such a course of action soon led to surprising research results. People began carrying out well-thought-out experimental works in the field of plant nutrition in that period. Attempts to draw conclusions from experiments can be exemplified by the carefully planned quantitative research of Jean Baptiste van Helmont (1579-1644) - a Belgian physician. His research concerned the way plants feed. He planted a willow twig that weighed 5 pounds ( 1 pound equals 0.454 kilograms) into a container filled with 300 pounds of accurately weighed salt. The soil that was used in the experiment had been previously "dried in a furnace". The rooted tree grew for 5 years. It was watered with storm water (without mineral components). The fact that the willow grew in a ceramic pot, and that a perforated cover was placed on top of the pot to avoid "dust", is indicative of the thoroughness of that research. The produced mass of the willow amounted to 164 pounds after that time, with simultaneous reduction in soil mass only by 2 ounces ( 1 ounce equals $28.35 \mathrm{~g}$ ). Jean Baptiste van Helmont drew a conclusion from that extremely laborious experiment that "the entire mass of the willow had been produced only from water", meaning that water had been the only available food for the growing tree $[3,9,10]$. This seemingly very convincing experiment has been repeated by many outstanding scientists of that period in England, France, Germany and Russia. With their prestige, they contributed to cementing this incorrect theory of plant nutrition for a long time. As a result, for nearly two centuries (17th and 18th) the dominant view was that plant biomass comes from water [6]. To a great extent it was understandable because in those times the phenomenon of photosynthesis was still unknown and people did not know carbon dioxide, as "food" for plants, can be present 
in air [10]. Van Helmont rejected the then dominant concept of four elements (earth, fire, air and water), believing that only water and air are the "real elements". Rejection of the concept of four elements gave an impulse for further research on plant nutrition.

Francis Bacon (1561-1626), in his work entitled "Sylva Sylvarum", published 25 years after his death, described one of the first experiments in the field of mineral plant nutrition. In those experiments concerning seed germination and wheat seedling growth, he added animal droppings, ash, salt, lime, sea sand and soot to the hydroponics, and he analyzed the obtained results [6]. While cultivating plants in hydroponics, Bacon also observed the growth of land plants and was unable to avoid incorrect interpretations in that area. $\mathrm{He}$ presented an "incorrect" thesis that soil is necessary only for holding plants in vertical position [10]. John Woodward (1655-1728), an English researcher, showed great research intuition by predicting, to some extent, the importance of soil in plant nutrition. In a simple experiment where he placed a mint twig in three environments (distilled water, water from the Hyde Park, and the same water with added soil) he showed that, contrary to what Van Helmont claimed, soil is the material from which plant biomass is produced, not water [6]. In the 17th century, Marcello Malpighi (1628-1694) started paying attention to green leaves as an important organ of plant nutrition. Malpighi - an Italian biologist and doctor - being a farmer's son, ran a farm and that is why he was interested in fertilization and plant nutrition. His views gave an impulse for starting research on photosynthesis of plants [10].

In the middle of the 18th century there was great interest in cultivated plants (from the point of view of their nutritive values) as food for humans, fodder for animals and natural medicines. It was a great impulse for research on plant nutrition. Antoine-Laurent de Lavoisier (1743-1794), a French physicist and chemist, proved, among other things, that oxygen plays a key role in animal and plant respiration and in all oxidation processes. Lavoisier's discoveries made it possible to overthrow the phlogiston theory, which postulated that materials release a substance called phlogiston when they burned, and he laid foundations for the development of modern chemistry [11]. Another scientist, Joseph Priestley (1733-1804), an English chemist who discovered oxygen, showed that plants, contrary to animals, purify air since they emit oxygen. However, his experiments allowed him to draw this conclusion not in all circumstances. Jan Ingen-Housz (1730-1799), a Dutch biologist, physiologist and chemist, was the first to state that plants emit oxygen, meaning that they "purify" air only in sunlight; in dark they emit carbon dioxide. His research results were an important step that led to explaining the mechanism of plant nutrition by assimilation of carbon dioxide [10, 12]. Jean Senebier's (1742-1809) works were another important advance in research on plant nutrition. In his works, he showed that the volume of oxygen released during plant life processes equals the volume of absorbed carbon dioxide, which brought him to the conclusion that oxygen released during photosynthesis comes from the decomposition of absorbed carbon dioxide [6].

The first scientist who applied Lavoisier's principles of modern chemistry and used the results of earlier studies on plant nutrition was Nicolas-Theodore de Saussure (1767-1845), a Swiss chemist and botanist, a pioneer in research on phytochemistry and physiology of plants. He dealt with, among other things, photosynthesis and the balance of chemical compounds (including carbon dioxide and water) produced by herbaceous plants. In his work entitled "Chemical research on plants" he writes that "...the atmosphere is the main source of carbon in a plant, and soil is only a supplier of ash components and water" [13]. Therefore, based on precise experiments combined with chemical analysis, he reaches a conclusion that a plant builds organic substances from carbon dioxide taken from air and 
from water taken up from soil. Apart from explaining the role of oxygen and carbon dioxide in these processes, the author draws attention to the role of nutrients taken up from soil from which both nitrogen and ash components come [1,9]. German researchers such as Carl Sprengel (1787-1859) and Arend Fredrich Wiegmann (1770-1853) continued research on the role of inorganic nutrients in plant nutrition, and the results they obtained confirmed de Saussure's findings [2].

The 18th century, especially its second half, proved to be very creative for environmental sciences. A way to understand the mechanisms of plant nutrition had been opened, although it would take many years before the new discoveries would sink into the minds of researchers dealing with these issues.

The 19th century was a breakthrough in explaining the nature of plant nutrition. Two hypotheses of German scientists appeared in that period: „The humus theory for plant nutrition" by Albrecht Daniel von Thaer (1752-1828) and „Theory of mineral plant nutrition" by Justus von Liebig (1803-1873).

The humus theory for plant nutrition. In the cycle of works entitled (1809-1812) Grundsatze der rationellen Landwirtschaft, Albrecht Daniel von Thaer cemented the earlier views of Johan Gottschalk Wallerius (1709-1785) about the "humus theory for plant nutrition". According to this theory, humus is the main source of plant nutrients, next to the previously recognized role of water, obviously. In Thaer's opinion, minerals played only a supporting role in providing plants with humic compounds. Therefore, the whole soil fertility depends only on the amount of humus present in it. He presented his views in his work "The Principles of Agriculture". Thaer was a physician and an agronomist from profession. He announced his views in the Agricultural Academy in Moglin, Germany (1806), which he founded and which was the first agricultural academy in Europe. He was also an advocate of crop rotation and potato cultivation. He was a professor at the university in Berlin. In Thaer's time, Humphry Davy (1778-1829), an English chemist and physicist, also conducted research on plant nutrition. He published a book entitled "Elements of Agricultural Chemistry" in London, and in it he drew attention to humus as the basic food for plants [14]. Albrecht Thaer's works and scientific studies exerted a particularly strong effect on Michal Oczapowski (1788-1854), a Polish agronomist, professor at the University of Vilnius who later became director of the Institute of Agronomy in Warszawa-Marymont. Oczapowski became a fervent supporter of the humus theory. Inspired by foreign literature, studies under, among others, Thaer in Moglin (Germany), and based on his own experiments, he published in print "The principles of agricultural chemistry" (1818), and then "The principles of agronomy" (1819). Few people know that it was Oczapowski who coined the term "humus", which functions to this day [15]. Both Davy and Oczapowski were supporters of the humus theory for plant nutrition, and they based their works on this idea.

Theory of mineral plant nutrition. The humus theory for plant nutrition was the dominant concept explaining the essence of plant nutrition for tens of years. Justus von Liebig (1803-1873), a chemist, was the first to explain, through his experimental works, the basics of the problem of mineral plant nutrition. In 1841, a publication entitled "Die Organische Chemie in ihrer Anwendung auf Agrikultur und Physiologie" - "Organic Chemistry in Its Applications to Agriculture and Physiology" was released, with a new theory of mineral plant nutrition [16]. This book opens a new chapter in the development of the science of plant nutrition. It attracted great interest not only in scientific world but also among a lot of farmers. Liebig wrote that not humus but mineral salts (are taken up with 
water by roots from soil) and carbon dioxide assimilated from air in the photosynthesis process are the direct food for plants. For stable plant yields, soil should be supplied with mineral fertilizers in order to replenish the deficiency of nutrients caused by their removal from the field along with plant yield. Liebig formulated his theory about mineral plant nutrition based on other scientists' studies, and also through deduction from a chemical analysis of plants. As a chemist and analyst, he conducted many studies on the chemical composition of plants. He determined that plants release carbon, hydrogen, oxygen and nitrogen (which are present in them) during combustion, and composition of the generated ash always includes phosphorus, sulfur, calcium, potassium, magnesium, silicon, and many times sodium. However, Liebig, like many of his predecessors, did not avoid incorrect conceptualizations; for example, regarding the issue of nitrogen as a nutrient for plants. In the initial period of his scientific activity, Liebig did not attribute too much importance to nitrogen in fertilization. He believed that nitrogen occurs in the atmosphere both in the form of ammonia formed, among other things, from elemental nitrogen and water, and in the oxidized form as a result of electrical discharges, and that it enters soil with precipitation, in a sufficient amount to satisfy plant nutrient requirements. That is why, from Liebig's point of view, valuable in manure is mainly its ash fraction and which contains potassium, phosphorus and other minerals necessary for plants [2, 9]. In his theory, Liebig marginalized the issue of nitrogen fertilization, assuming incorrectly that plants provide themselves with nitrogen (like with carbon dioxide) through a closed circulation cycle in nature. In 1842, a German scientist Carl Sprengel (1787-1859) formulated the "theory of minimum" in agricultural chemistry, which now is known as "Liebig's law of the minimum". This theory says that plant growth is limited by the essential nutrient at the lowest concentration. Liebig, as a known researcher, popularized this theory. That is why he is incorrectly credited with its authorship. Liebig's law of the minimum revolutionized contemporary views about fertilization which were dominated by the humus theory, both among scientists and farmers. This law is still valid and is the basis for current systems of mineral fertilization diagnostics $[2,6]$.

However, Liebig's conviction that only ash components decide on the value of manure, and that nitrogen does not play a significant role in this area, was strongly criticized by a French chemist and agronomist Jean Baptiste Boussingault (1802-1887). Based on the research carried out at the world's first agricultural experimental station, which he had founded at his estate in 1834, he attributed the greatest importance to nitrogen as a factor whose deficiency is the major cause of the decrease in plant yields due to soils being depleted of this nutrient. He also believed that the presence of nitrogen in natural fertilizers (formerly known as organic fertilizers) is the main yield-forming factor. The French scientist, apart from observing the effect of nitrogen on plants and their yielding, also studied the process of carbon assimilation by plants. He formulated, before Justus von Liebig (before 1840), the theory of mineral plant nutrition, which, however, was not published. Boussingault was the first scientist to pay attention to circulation of elements (which are important for plant nutrition) in nature. Experiments conducted at one of the world's first agricultural stations, "Rothamsted" in Harpenden, England, in 1843 by John Bennet Lawes (1814-1900) and Joseph Henry Gilbert (1817-1901) also confirmed the fertilizing significance of nitrogen as the basic fertilizer component. It was shown that the yield-forming effect of manure is much better than that of ash obtained from manure incineration [9]. 
After many years of research, Boussingault's new views on the role of nitrogen in plant nutrition were coupled with the role of ash components, promoted by Liebig, formulating a coherent concept that would form the basics of mineral plant nutrition, which is still up to date.

Other discoveries, confirming the important role of minerals in plant nutrition, were made by German researchers: Hermann Hellriegel (1831-1895) and Hermann Wilfarth (1853-1904). The above-mentioned scientists dealt with the issues of plants making a direct use of elemental N. In 1886, they showed that Fabaceae plants (formerly referred to as papilionaceous plants) are capable of using this nitrogen by means of root nodules and with participation of microorganisms living in them [17].

Both supporters and those opposing the new theory of plant nutrition tried to obtain as much material evidence to support their standpoint as possible. It was then that a special method of conducting vegetation experiments in sand cultures was developed, and then it was implemented by Wilhelm Knop (1817-1891) and Julius Sachs (1832-1897) in hydroponics. The method makes it possible to exclude particular minerals from an artificial nutrient solution and to determine whether the incorporated nutrient is necessary or unnecessary for plant growth and development $[2,18]$. Moreover, Sachs proved that starch is formed in chloroplasts only in the light. According to Sachs, this is the first "visible" product of photosynthesis [10].

The theory of mineral plant nutrition, published by Justus von Liebig, is one of the most important scientific discoveries in agriculture. It is a model example of how to implement innovations in the 'technology demand' system, which consists in taking innovative actions as a result of scientific discoveries in another industry. In this case, the discovery of the "Law of mineral plant nutrition" and the "Law of the minimum" was not only the foundation for pioneering mineral fertilization of plants, but also led to formation and dynamic development of the fertilizer industry. Just like Liebig's discoveries constituted the beginning of modern agricultural chemistry, John Lawes's patent (granted in 1842) for the manufacture of superphosphate as well as setting up the first factory to produce it (in Liverpool in 1848) should be regarded as the beginning of the mineral fertilizer production technology [19].

In the first edition of his book, Justus von Liebig, the creator of the theory of mineral plant nutrition, completely rejected the humus theory for plant nutrition formulated by Thaer. Later, however, after scientific reports made by other researchers, including the ones mentioned above, Liebig began appreciating the importance of humus for soil fertility, believing that mineral fertilizers are effective only when soil is in good condition, to which humic compounds contribute. Currently, it is commonly assumed that apart from using mineral fertilizers to maintain and increase soil fertility, natural and organic fertilizers are also necessary, since they act as the substrate for humus formation [2, 20].

Liebig and Boussingault are listed among founders of modern agricultural chemistry. The global importance of the principles of mineral fertilization (formulated by them) for agriculture is well explained in a sentence from Liebig's lecture at a university: "Rome has thrown the entire fertility of Sicily into the gutter". In this graphic way he wanted to say that each ship that brought Sicilian grain to Rome also brought minerals, which, instead of returning to soil with excrements, disappeared in municipal waste. The result was that fertile soils of Sicily, which had served as a granary of Rome, underwent impoverishment and became one of the poorest in the world [21]. In a long-term perspective, popularization of industrial production of mineral fertilizers, which constitutes practical application of the 
scientific theory, became the foundation of modern agriculture, and in modern times enabled concentration of human settlements in the form of large urban agglomerations with populations of tens of millions of people. In past civilizations, minerals taken up from the soil could not be restored. In this context it is clear what a great barrier for the development of past civilization was the lack of agricultural knowledge on plant nutrition and fertilization.

\section{Present Day, the 20th century}

Scientific discoveries regarding mineral plant nutrition as well as the import of relatively expensive guano fertilizers from South America and soda nitre from Chile, and also a vision of famine as a result of exploitation of Chile saltpetre deposits were the driving force behind chemical innovations, which includes a dynamic growth of the fertilizer industry in the 20th century.

One of the greatest achievements in this area was implementation (at industrial scale) of the catalytic process of producing ammonia from atmospheric nitrogen. Thus obtained ammonia became the basic fertilizer intermediate product in the growing fertilizer industry. Fritz Haber's (1868-1934) technological success, consisting in implementing a unique process (at industrial scale) in Oppau, Germany, in 1911, was possible thanks to the cooperation with Carl Bosch (1874-1940), a chemist and engineer. Most of the modern fertilizer technologies were introduced in the first three decades of the 20th century (ammonia, nitric acid, triple superphosphate). Achievements of both outstanding scientist, Haber and Bosch, were honored with two Nobel prizes: Fritz Haber in 1918, and Carl Bosh in 1931 together with Friedrich Bergius [22]. What is more, it was in that period that herbicidal properties of some fertilizers such as nitrolime, kainite, soda nitre, ammonium sulfate, and also of non-organic compounds such as ferric sulfate, sodium arsenite, and arsenic and boron compounds started to be used [19].

The amazing effectiveness of the 'chemicalization' of agricultural production and utilization of the achievements of the Green Revolution in the 1980s gave the technological capacity to feed the earth's population [23]. The Green Revolution was initiated by Norman Ernest Borlaug (1914-2009), who was awarded the Peace Nobel Prize in 1970 for his work. Dynamic development of the fertilizer industry in that period as well as cultivation of high-yielding varieties of wheat, maize with a high protein content, contributed to an increase in food production (which met the demand of the world's population). However, that did not solve the problem of feeding the population.

In the middle of the 20th century, when it seemed that mineral fertilizers were the 'cure' that would ensure food security for mankind, people became aware of the negative effects of the increasing chemicalization of agriculture. There is no denying the fact that the use of mineral fertilizers in agriculture is one of the greatest discoveries of our time. The reason is that by having an effect on the chemical equilibrium in the soil environment and an indirect effect on human health, it is of enormous importance to the present-day world. It allows to prevent soil impoverishment, which was so greatly felt by old civilizations. The use of fertilizers allowed for a great increase in yields from a unit of area, and thus for a reduction in food prices. Therefore, it contributed significantly to the improvement of living standard of modern societies. This discovery, so important for the present day, also has its dark sides [21]. People realized that the increase in fertilizer doses introduced into soil not only makes the unit yield increase smaller and smaller, but after exceeding the 
upper productivity limit, a reduction in yield takes place (the more excessive the fertilizer dose, the greater the reduction). Further studies showed that excessive or unbalanced fertilization contributes to deterioration of the biological value and quality of yields. Large-scale research on the effect of fertilization on the content of minerals and main organic substances (protein, amino acids, vitamins, hormones, enzymes and the like) was launched. That research led Andre Voisin (1903-1964), a French researcher, to the discovery of two new fertilizer laws in the 1960s. These laws are known as the Law of the Maximum and Law of the priority of biological quality.

The former says that "an excessive amount of available substance in soil limits the effectiveness of other substances and in consequence leads to a decrease in yields". The latter, which relates to the relationship between fertilization and yield quality, says that "the main goal of fertilizer use should be to improve the biological quality ${ }^{3}$ which is of higher importance than the amount of yield" [21]. These laws, next to the Liebig's law of the minimum, are the basis of the present-day systems of fertilization diagnostics in agriculture.

In the middle of the 20th century, apart from dynamic growth of the fertilizer industry, isotope techniques began to develop; they were used in research on mineral plant nutrition. A number of radioactive macroelements and microelements was also commonly used for studying the processes of uptake and accumulation of nutrients in plants. These techniques, despite their invasiveness, confirmed the nature of uptake and necessity of nutrients in plants [24].

\section{Modern times, the 21st century}

In modern times, agriculture is an example of incredible symbiosis and cooperation in the area of practical application of scientific research in the field of agricultural chemistry and chemical technology, biology, physiology of mineral nutrition and other related sciences. In current agriculture, which includes, among other things, crop management, mineral fertilizers and agrochemicals, scientific studies still play a very significant role. However, the hierarchy of the factors of progress in agriculture has recently changed. While the driving force in agriculture in the 20th century was the widely understood chemical progress (the dominant part of which were mineral fertilizers), the 21 st century is an era of biology. The beneficiaries of the great biological progress are primarily two fields: medicine and agriculture. In relation to agriculture, this progress is represented by, above all, creation of new cultivars which are more and more precisely adjusted to the requirements of the consumer and of the agri-food industry. The role of mineral fertilization is still very important, but focused on fertilizer technologies which are adjusted to the trends of how to use plants and to their variety requirements. By creating new plant genotypes, biological progress sets (to some degree) frameworks which specify the measures which need to be taken in the area of fertilization and which must be precisely adjusted to the ever changing (along with the progress in creating new genotypes of cultivated plants) new conditions.

The effect of these changes is a fundamental increase in the selection of fertilizers, which started already at the end of the 20th century. New multi-nutrient and microelement fertilizers appeared. They allowed for accurate adjustment of fertilization to soil conditions

\footnotetext{
${ }^{3}$ According to Voisin [21] biological quality is understood as the sum of individual plant nutrients which are critical for maintaining normal metabolism in a living organism (animal or human) for which a plant serves as food.
} 
(soil reaction and abundance in nutrients), requirements of the cultivars and agricultural technology. Currently, it is estimated that the fertilizer market includes almost a thousand different types of fertilizers $[1,25]$.

Agriculture is an example of initiating the growth of many industries, including chemical technology, creating a real demand for chemical products needed for the agricultural economy. Development of agricultural sciences, and also new achievements of chemical technologies, substantiate the introduction of chemical innovations in plant nutrition and in increasing plant yields. However, chemical innovations in plant nutrition include various strategies used separately or in combination. For example, genetic engineering is used to improve the uptake of macro and micronutrients by plants. One of the greatest successes in this area was the expression of ferritin - a protein that stores iron in a bioavailable form. Recombinant soybean ferritin was added to many grains, and pea ferritin was expressed in rice. Currently, while creating new technologies in the field of mineral plant nutrition, processes of biosorption (in relation to dead biomass) and bioaccumulation (mineral fixation by living organisms) in the production of fertilizer components with microelements are also used [26].

Research is being conducted to gain a more complete understanding of physiological processes of plants, biochemical changes, and to work out methods for designing new compounds for plant feeding and protection. Another research focuses on increasing the effectiveness of nutrient uptake from soil and on the use of biofertilizers for biological nitrogen fixation.

According IFA (International Fertilizer Association), "Without fertilizers, human life is unsustainable" [27]. That is why it is justified to introduce various innovations in chemical products, including fertilizers. Current studies cover modernization of the production of fertilizers and agrochemicals, despite the fact that they meet the requirements of the IPPC (Integrated Pollution Prevention Control) Directive and BAT (Best Available Technique) standards. Nowadays, the produced fertilizers are designed to meet the needs of specific plant species and to adapt to the conditions of local agriculture. Production of mixed fertilizers in the Bulk Blending system (combinations of customized fertilizers) is being prepared and implemented on a large scale. The necessity to implement and popularize new suspension fertilizers, polyphosphate-chelated microelement fertilizers, amino acid based microelement fertilizers, and liquid fertilizers with growth stimulants (plant hormones) and also with substances producing specific effects during vegetation (such as controlling the budding, flowering, stem shortening) is justified. Innovative chemical products created as a result of multidisciplinary technological research involving fertilizers coated with different polymers for slow and controlled release of nutrients during plant vegetation are a new trend. Application of domestic bentonite clay minerals (as nutrient adsorptive carriers) in fertilizer technologies offers many as yet unused possibilities. They can be utilized to improve soil structure, increase soil water capacity, and also as carriers of microelements. Fertigation system (irrigation combined with fertilization) is another chemical innovation used in agriculture. The drip fertigation system will undoubtedly evolve in fruit culture and market gardening. This system involves supplying nutrients to the plant root system using a system of polyethylene pipes. This system requires fertilizer products of assumed properties, without the tendency for salt accumulation on pipe surfaces, which means that it should be adapted to water quality. It is more and more often the case that such fertilization systems are precisely controlled with the use of computer techniques. Great hope is also placed on the development of plant 
growing in hydroponic, water, aeroponic systems without soil participation, or using artificial soil, mineral wool substrate and substrate made of other materials [28-31]. These systems also require plant nutrition with fertilizers with composition specially designed for specific requirements of species and even varieties of plants. In large-area agriculture, techniques of in-depth application of fertilizers are being developed, with the use of specialist cultivation and fertilization units that allow for better utilization of fertilizer components by plants and thereby for the reduction of their losses to the environment. Carl Zimmer, a professor at the University of Bonn, was the creator of the concept of in-depth application of fertilizers. In the second half of the 20th century he showed that granular fertilizers, when placed at a certain depth $(10-30 \mathrm{~cm})$, create favorable conditions for deeper plant rooting, showing specific chemotropism, which increases plant resistance to water stress and as a result increases fertilizer use.

Another challenge of the modern times is the problem of waste and the possibility of recovering nutrients that can be found in it, through fertilizer use. As is well known, food products enter metropolitan areas, whereas minerals and organic substances found in domestic waste find their way (in the form of sewage) to surface waters or are accumulated on landfills, creating huge environmental problems and the necessity to incur high costs of their utilization [32]. New innovative methods of processing this waste into organic and organic-mineral fertilizers have been recently elaborated. This also applies to agricultural waste generated on modern specialist animal farms with high animal concentration (mainly pigs and poultry), and also in mushroom-growing cellars or agricultural biogas plants [29, 33].

Detoxification of these products, and also (through proper formulations) making their composition optimal for the nutrient requirements of cultivated plants, create challenges for science. Studies are also being conducted on the processing of slaughterhouse waste into mineral-organic fertilizers which are safe in sanitary terms [34]. Another example of chemical innovation is the new generation of fertilizers produced from fishing industry waste, and also the use of crustacean skeletons and clam shells as raw materials for the production of fertilizers from kelp. These fertilizers contain almost all microelements, and also a lot of phosphorus, magnesium, calcium and potassium, as well as auxin compounds growth hormones [19].

Plant biofortification (enrichment) is another chemical innovation. This term is defined as the processes or procedures whose purpose is to increase the content of some elements, nutrient compounds and vitamins in plant yield in order to improve its biological quality, and, as a result, to improve the health of food consumers. As it is known, new plant varieties provide a possibility of high yields. On the other hand, they are have a lower content of some elements. What is more, a long-term tendency of decreasing content of certain nutrients in soils can be observed on many agricultural areas. Studies in this field justify the purposefulness of creating new specialist microfertilizers which provide the possibility of safe plant enrichment with deficit substances. This applies, among other things, to iodine, zinc, molybdenum, selenium [35, 36].

Reaching innovation goals in plant nutrition requires comprehensive, interdisciplinary studies not only on chemical products and the processes of their production, but also on the useful properties of these products.

Precision Agriculture (or Precision Farming) is the most recent chemical innovation in plant nutrition [37]. It is an entire set of technologies that forms an agricultural system which also includes fertilization and which adapts all elements of agricultural technology to 
the changing conditions on individual fields under cultivation [38]. It can also be defined as farming with the support of information technologies for obtaining higher yields of better quality with simultaneously reducing the costs of production and limiting the environmental pollution $[39,40]$.

\section{Milestones in the development of sciences on plant nutrition}

Many scientists stress that one cannot understand the present state of knowledge without knowing the history of its development. Presentation of some facts from the history of plant nutrition (Table 1) appears to be substantiated. In various studies, treatises, textbooks, and scientific publications, there is a repository of creative thoughts and hypotheses of scientists who, despite incredibly primitive conditions and tools, conducted well-thought-out experiments. Some conclusions show the genius of the human mind. In other cases, conclusions are not real, but this often results from lack of knowledge from other branches of science, e.g. chemistry, physics, biology, physiology.

Table 1

Milestones in the development of plant nutrition

\begin{tabular}{|c|c|c|}
\hline Year & Author & Issues \\
\hline 1600 & Van Helmont & What can be used as food for plant growth \\
\hline 1772 & Priestley & Plants release oxygen from leaves into the atmosphere \\
\hline 1804 & De Saussure & Apart from $\mathrm{CO}_{2}$, also water takes part in photosynthesis \\
\hline 1806 & Thaer & First agricultural academy in Moglin (Germany) \\
\hline After 1800 & Thaer & The humus theory for plant nutrition \\
\hline 1834 & Boussingault & Theory of mineral plant nutrition \\
\hline 1841 & Liebig & Theory of minimum in agricultural chemistry; Liebig's Law of the \\
\hline 1842 & Sprengel, Liebig & Patent: a way to obtain single superphosphate \\
\hline 1842 & Lawes & First superphosphate factory in Liverpool \\
\hline 1848 & Lawes & Synthesis of ammonia \\
\hline 1886 & Hellriegel and Wilfarth & Discovery of the phenomenon of nitrogen fixation by rhizobia \\
\hline 1911 & Haber and Bosch & Green Revolution, technological capacity to feed the world \\
\hline 1970 & Borlaug & Precision Agriculture \\
\hline 1994 & Robert & Innovative fertilizers \\
\hline After 2000 & Scientists & \\
\hline
\end{tabular}

According to this short survey, the most important chemical innovations in plant nutrition took place at the turn of the 19th and 20th centuries.

\section{Agricultural experimental stations}

Liebig's contributions as the creator of the theory of mineral plant nutrition have inspired many scientists to start fertilizer experiments, some of which are still being conducted. Table 2 shows the oldest and the most famous agricultural experimental stations; they are presented in a chronological order. These stations were established in Europe, including the European part of Russia, and in the United States of North America. They have played an enormous role in the assessment of new fertilizers and agricultural technologies, and also allowed to assess their environmental impacts, which is currently of particular importance [9, 41-43]. Understanding the effects of mineral fertilizers on the plant and soil requires monitoring of changes taking place at various levels of organization 
of agricultural and ecological systems over time and space. Due to the changes (taking place over the years) in soil fertility and owing to the changes in yielding and qualitative composition of plants (which remain strictly connected with soil), long-term static field experiments have proven to be a very useful research tool [44].

Table 2

The oldest and the most famous agricultural experimental stations

\begin{tabular}{|c|c|c|}
\hline Established in & Founder / Institution & Name, place of creation \\
\hline 1834 & Jean Baptiste Boussingault & Alsace, France \\
\hline 1843 & John Bennet Lawes & Rothamsted in Harpenden, England \\
\hline 1872 & Regional Government of Wallonia & Gembloux, Belgium \\
\hline 1875 & Government of France & Grignon, France \\
\hline 1876 & George Espy Morrow & Morrow Plots, Illinois, USA \\
\hline 1878 & Julius Kuhn & Halle, Germany \\
\hline 1888 & J.W. Sanborn & Sanborn Fields, Missouri, USA \\
\hline 1894 & The Government of Denmark & Ascot, Denmark \\
\hline 1902 & Wilhelm Schneidewind; Grobler & Bad Lauchstadt, Germany \\
\hline 1912 & Dmitrij Nikolaevich Prianisznikow & Moscow, Russia \\
\hline 1923 & $\begin{array}{c}\text { Jozef Mikułowski-Pomorski, Marian } \\
\text { Gorski } \\
\end{array}$ & Skierniewice, Poland \\
\hline 1968 & Kazimierz Mazur & Czarny Potok, Poland \\
\hline
\end{tabular}

\section{Summary and conclusions}

Chemical innovations in plant nutrition are presented from the historical perspective, presenting the most important, but subjectively chosen, achievements.

The great progress in plant nutrition, which has been observed in recent years, is a result of the achievements in, among other things, sciences such as chemistry, chemical technology, physics, biology, physiology of mineral nutrition, and in the use of modern analytical techniques and using precise research equipment. New, innovative research methods have revolutionized the possibilities of measurement of plant nutrition processes, from which proper conclusions can be drawn, thus eliminating the errors. The development of studies on mineral plant nutrition results, among other things, from the necessity to increase food production whose goal is to feed approximately 9 billion people by the half of this century. It is an obligation to the society, and it must be met by, among others, farmers, biologists and chemists.

One should agree with the opinion of Arnold Fink, an outstanding German agricultural chemist, that "Scientific theories and hypotheses can be used in agriculture as long as they find confirmation when confronted with nature".

\section{Acknowledgements}

The authors wish to thank Agnieszka Baran, $\mathrm{PhD}$, for the inspiration to write this article. We would like to thank Professor Michal Kopec for his comments on the issues discussed in this paper. We would also like to thank Michal Antonkiewicz, a student at the Institute of Classical Philology of the Jagiellonian University, for looking for aspects connected with plant nutrition in Latin sources and their translations. 


\section{References}

[1] Clarkson DT, Hanson JB. The mineral nutrition of higher plants. Ann Rev Plant Physiol. 1980;31:239-298. DOI: 10.1146/annurev.pp.31.060180.001323.

[2] Fageria NK. The Use of Nutrients in Crop Plants. Boca Raton: Taylor Francis Group; 2009. https://www.crcpress.com.

[3] Starck Z, Pietkiewicz S. Rozwój fizjologii roślin na tle 200 lat kształcenia rolniczego na ziemiach polskich. Od Instytutu Agronomicznego na Marymoncie do SGGW na Ursynowie. [Development of plant physiology on the background of agricultural education on Polish terrains. From Institute of Agronomy in Marymont to Warsaw University of Life Sciences-SGGW in Ursynów]. Warszawa: SGGW; 2016. http://agrobiol.sggw.pl/fizjologia.

[4] Zemanek A, Savoir AU, Zemanek B. Archives Natural History. 2008;34;1:87-108. DOI: 10.3366/anh.2007.34.1.87.

[5] Mikołajczyk I. Marek Porcjusz Katon. O gospodarstwie rolnym. (Marcus Porcius Cato. About the farm). Toruń: Wyd. Nauk. UMK; 2009. http://www.wydawnictwoumk.pl/pl/products/2105/o-gospodarstwierolnym.

[6] Strebejko P. Czym żywi się roślina. Warszawa: PWN; 1974.

[7] Zemanek A, Zemanek B. Roślina i sacrum w historii cywilizacji [The plant and the sacrum in the history of civilization]. In: Domański B, Skiba S, editors. Geografia i Sacrum. 2005;2:471-480. http://www.geo.uj.edu.pl/publikacje,000080.

[8] Finck A. Fertilizers and Fertilization: Introduction and Practical Guide to Crop Fertilization. Basel: Weinheim, Deerfield Beach (Fla): Verlag Chemie; 1982. https://books.google.pl/books/about/ Fertilizers_and_Fertilization.html?id=qY0dAQAAMAAJ\&redir_esc=y.

[9] Fotyma M. Chemik. 2010;64(7-8):499-510. http://miesiecznikchemik.pl/wp-content/uploads/2015/ 11/SLONECZNA-CHEMIA-Ksi\%C4\%85\%C5\%BCka-DRUK.pdf.

[10] Starck Z. Kosmos. Problemy Nauk Biol. 2014;63;4(305):569-589. http://kosmos.icm.edu.pl/PDF/2014/569.pdf.

[11] Guerlac H. Chemistry as a branch of physics: Laplace's collaboration with Lavoisier. Historical Stud Phys Sci. 1976;7:193-276. DOI: 10.2307/27757357.

[12] Starck Z, Niemyska B. Botanical News. 1998;42;2:27-36. http://bomax.botany.pl/pubs/data/ article_pdf?id=2358.

[13] Gunter F, Keller C, Meunier JD. Agron Sust Develop. 2012;32(1):201-213. DOI: $10.1007 / \mathrm{s} 13593-011-0039-8$.

[14] Davy H. Elements of Agricultural Chemistry. In a Course of Lectures. London: Glasgow: Richard Grifein Company London; 1844. http://www.archive.org/details/elementsofagricu014743mbp.

[15] Malicki L. Post Nauk Roln. 1989;36(41);1/226:13-25. http://pnr.czasopisma.pan.pl.

[16] Ploeg RR, Bo W, Kirkham MB. Soil Sci Soc Am J. 1999;63;5:1055-1062. DOI: 10.2136/sssaj1999.6351055x.

[17] Burris RH. Plant Soil. 1998;108;1:7-14. DOI: 10.1007/BF02370094.

[18] Hoagland DR, Arnon DI. The Water-Culture Method for Growing Plants without Soil. California Agriculture Experiment Station. 1950. https://archive.org/details/watercultureme3450hoag.

[19] Górecki H, Chojnacka K, Dobrzański K. Innowacje chemiczne w rozwoju zrównoważonego rolnictwa. [Chemical innovations in the development of sustainable agriculture]. In: Misja nauk chemicznych. Marciniec B, editor. Poznań: Wyd. Nauka i Innowacje; 2012:169-192. http://sprzedajemy.pl/misja-naukchemicznych-bogdan-marciniec-nr42465737 .

[20] Gondek K. J Elem. 2012;2/2012:231-245. DOI: 10.5601/jelem.2012.17.2.06.

[21] Voisin A. Fertilizer Application; Soil, Plant, Animal (translation by Herriott CTM.). Springfield Ill: Thomas; 1965.

[22] Lindström B, Pettersson LJ. Cattech. 2003;7;4:130-138. DOI: 10.1023/A:1025001809516.

[23] Ortiz R, Trethowan R, Ferrara GO, Iwanaga M, Dodds JH, Crouch JH, et al. Euphytica. 2007;157;3:365-384. DOI: 10.1007/s10681-007-9375-9.

[24] Kozhakhanow TE, Lukashenko SN, Larionova NV. J Environ Radioact. 2014;137:217-226. DOI: 10.1016/j.jenvrad.2014.06.026.

[25] Filipek-Mazur B, Lepiarczyk A, Tabak M. Ecol Chem Eng A. 2011;20(11):1351-1358. DOI: 10.2428/ecea.2013.20(11)123.

[26] Ditta A, Arshad M, Ibrahim M. Nanotechnol Plant Sci. 2015;55-75, DOI: 10.1007/978-3-319-14502-0_4.

[27] IFA, Annual Report. Feeding the world on combating climate change. 2009. www.fertilizerseurope.com.

[28] Antonkiewicz J, Jasiewicz C, Koncewicz-Baran M, Sendor R. Acta Physiol Plant. 2016;38;40:11. DOI: 10.1007/s11738-016-2062-5. 
[29] Baran S, Wójcikowska-Kapusta A, Żukowska G, Bik-Małodzińska M, Wesołowska-Dobruk S. Archiv Environ Protect. 2015;41;2:82-88. DOI: 10.1515/aep-2015-0022.

[30] Hershey DR. American Biol Teacher. 1994;56(2):111-118. DOI: 10.2307/4449764.

[31] Ghaly AE, Kamal M, Mahmoud NS. Environ Int. 2005;31:1-13. DOI: 10.1016/j.envint.2004.05.011.

[32] Antonkiewicz J, Kołodziej B, Bielińska E. Environ Sci Pollut Res. 2016B;23;10:9505-9517. DOI: 10.1007/s11356-016-6175-6.

[33] Gondek K, Mierzwa-Hersztek M. Soil Use Manage. 2016;32:357-367. DOI: 10.1111/sum.12285.

[34] Kopeć M, Gondek K, Mierzwa-Hersztek M, Antonkiewicz J. Saudi J Biol Sci. 2016. DOI: 10.1016/j.sjbs.2016.09.012.

[35] Zeigler RS. Plant Biotechnol. 2014:245-262. DOI:10.1007/978-3-319-06892-3_19.

[36] Smoleń S, Sady W, Rożek S, Ledwożyw-Smoleń I, Strzetelski P. J Elem. 2011;16;2:275-285. DOI: 10.5601/jelem.2011.16.2.11

[37] Heermann DF, Hosting J, Thompson SE, Duke HR, Westfall DG, Buchleiter GW, et al. Precision Agricult. 2002;3;1:47-61. DOI: 10.1023/A:1013374120356.

[38] Auernhammer H. Comput Electron Agric. 2001;30;1-3:31-43. DOI: 10.1016/S0168-1699(00)00153-8.

[39] Ribeiro PF, Santos JS, Santana J, Reino L, Beja P, Moreira F. Land Use Policy. 2016;58:165-172. DOI: 10.1016/j.landusepol.2016.07.018.

[40] Thorp KR, Hunsaker DJ, French AN, Bautista E, Bronson KF. Precision Agric. 2015;16;5:532-557. DOI: 10.1007/s11119-015-9393-x.

[41] Kopeć M. Plant Soil Environ. 2005;51(9):410-415. http://www.agriculturejournals.cz/publicFiles/50988.pdf.

[42] Mądry W, Studnicki M, Rozbicki J, Golba J, Gozdowski D, Pecio A, et al. Acta Agriculturae Scandinavica, Sect B - Soil Plant Sci. 2015;65:605-618. DOI: 10.1080/09064710.2015.1039053.

[43] Łabętowicz J, Mercik S, Barszczak T, Moskal S, Stepień W. Historia Chemii Rolnej w SGGW połączona z monografią prac naukowych. [History of agricultural chemistry in University of Life Sciences-SGGW with monograph of scientific papers]. Warszawa: SGGW; 2008. http://agrobiol.sggw.pl/srodowisko/pages/ strona-glowna/publikacje/2008.php.

[44] Kopeć M, Mierzwa-Hersztek M, Gondek K. J Elem. 2015;20;4:911-920. DOI: 10.5601/jelem.2015.20.1.791.

\title{
INNOWACJE CHEMICZNE W ODŻYWIANIU ROŚLIN OD STAROŻYTNEJ GRECJI I RZYMU PO CZASY NAJNOWSZE
}

\author{
${ }^{1}$ Katedra Chemii Rolnej i Środowiskowej, Wydział Rolniczo-Ekonomiczny \\ Uniwersytet Rolniczy im. Hugona Kołłątaja w Krakowie \\ ${ }^{2}$ Katedra Nauk o Środowisku Glebowym, Wydział Rolnictwa i Biologii \\ Szkoła Główna Gospodarstwa Wiejskiego w Warszawie
}

\begin{abstract}
Abstrakt: Niniejsze opracowanie stawia sobie za cel ukazanie, jak mozolnie na przestrzeni wieków kształtowały się poglądy dotyczące odżywiania roślin i powstawał fundament wiedzy przyrodniczej dotyczący tej problematyki. W publikacji przedstawiono także współczesne problemy i kierunki badań dotyczące odżywiania roślin, ukazując ich nowy wymiar, zdeterminowany $\mathrm{z}$ jednej strony potrzebą wyżywienia zwiększającej się w postępie geometrycznym populacji globu ziemskiego i z drugiej narastającymi problemami środowiskowymi $\mathrm{z}$ tytułu intensyfikacji produkcji rolniczej.
\end{abstract}

Słowa kluczowe: innowacje chemiczne, odżywianie roślin 